\title{
GREB1 wt Allele
}

National Cancer Institute

\section{Source}

National Cancer Institute. GREB1 wt Allele. NCI Thesaurus. Code C128183.

Human GREB1 wild-type allele is located in the vicinity of 2 p25.1 and is approximately 160 $\mathrm{kb}$ in length. This allele, which encodes protein GREB1, may plays a role in tissue responses to estrogen. Aberrant expression may be associated with estrogen receptorpositive breast carcinoma and other hormone-responsive neoplasms. 